\title{
Editorial
}

\section{Machado de Assis em tradução Machado de Assis in translation}

\section{HÉLIO DE SEIXAS GUIMARÃES}

Universidade de São Paulo

São Paulo, Brasil

\section{MARTA DE SENNA}

Fundação Casa de Rui Barbosa

Rio de Janeiro, Brasil

Ao encerrar o ano em que a revista completa sua primeira década, a MAEL traz um dossiê sobre Machado de Assis e a tradução, organizado por Pedro Meira Monteiro, da Princeton University, e Walter Costa, da Universidade Federal de Santa Catarina e da Universidade Federal do Ceará.

$\mathrm{O}$ assunto é tratado por várias perspectivas, incluindo desde os descaminhos das traduções da obra do escritor em seu tempo de vida até as recentes traduções para o inglês, espanhol e chinês.

O artigo de Lúcia Granja, "Três é demais! (ou por que Garnier não traduziu Machado de Assis?)", levanta, por meio de pesquisa em arquivos do Brasil e da França, hipóteses sobre as dificuldades impostas à obra do escritor para sua circulação na Europa, especialmente na França, onde o primeiro livro de Machado foi publicado apenas em 1910, dois anos depois da morte do escritor.

Também baseado em pesquisa documental, Wilton Marques, em "Machado de Assis e 'Maria Duplessis': a talvez primeira tradução", defende a hipótese de que a primeira tradução feita por Machado de Assis seria uma dupla tradução: do poema francês "Maria Duplessis", de Alexandre Dumas Filho, e a partir da tradução em prosa de Leonel de Alencar.

Os três ensaios seguintes tratam de três casos de tradução: para o espanhol, para o chinês e para o inglês. 
Em "Crônicas de Machado de Assis em tradução: marcas de edições vernáculas na tradução para o castelhano", Rosario Lázaro Igoa identifica a tendência, nas edições em espanhol, de distanciar as crônicas de suas marcas jornalísticas, ressaltando as características literárias, que as aproximariam do conto.

Em "Tradução e introdução das obras de Machado de Assis na China", de Zhihua $\mathrm{Hu}$ e Maria Teresa Roberto, conhecemos as principais traduções de obras de Machado de Assis para o chinês já realizadas, bem como os procedimentos de domesticação e estrangeirização adotados pelos tradutores de Quincas Borba, Dom Casmurro e Contos escolhidos.

Flora Thomson-DeVeaux, em "Reading Machado Through the LookingGlass: Case Studies from the Translations of Memórias Póstumas", compara as três traduções do romance para o inglês já publicadas, mostrando como as diferentes soluções tradutórias permitem conhecer melhor a grandeza e complexidade do texto de Machado de Assis.

Além do dossiê sobre tradução, o número traz outros cinco artigos, que focalizam o romance e o conto de Machado de Assis.

Kathryn Sanchez, em "'Coxa de Nascença': Misconceptions, Normalcy and the Aesthetics of Difference in Memórias Póstumas de Brás Cubas by Machado de Assis", analisa a célebre passagem do encontro entre Brás Cubas e Eugênia pelo viés teórico dos Disability Studies (Estudos de deficiência), numa abordagem inédita no âmbito dos estudos machadianos, que revela nuances sobre os parâmetros de beleza e normalidade vigentes no Brasil do século XIX.

"Dona Fernanda e a técnica narrativa de Quincas Borba" é o assunto de Maria Cecília Boechat, em artigo que retoma a polêmica em relação ao caráter da personagem feminina, procurando revê-la em conexão com procedimentos narrativos estruturadores do romance.

Em "'Ernesto de tal': o amor, o casamento por conveniência e o consórcio entre as instituições sociais", Naiara Santana Pita e Mirella Márcia Longo Vieira Lima examinam as visões dissonantes de amor e de casamento presentes na obra de Machado de Assis, por meio da análise do conto publicado na década de 1870 no Jornal das Famílias.

Por fim, Antônio Joaquim Pereira Neto e Marcello Moreira questionam as leituras da obra de Machado de Assis pela chave realista, por meio da análise da presença do fantástico no conto "O segredo do bonzo".

A edição traz ainda as resenhas de Histoires diverses, de Saulo Neiva, escrita por Luana Ferreira de Freitas e Cynthia Beatrice Costa; e de $A$ 
voluptuosidade do nada: niilismo e galhofa em Machado de Assis, de Vitor Cei, feita por Regina Sanches Xavier.

Na seção da tradição crítica, que desde o primeiro número abre a revista, a Machado de Assis em linha homenageia desta vez o escritor, professor e crítico português Jorge de Sena, cujo centenário de nascimento se completa em 2019, com a publicação do ensaio "O quinteto carioca de Machado de Assis". Nesse estudo do final da década de 1960, Sena propõe a leitura dos cinco últimos romances de Machado de Assis como uma unidade, em sintonia com o que de melhor se produzia então na crítica machadiana, conforme sugeriam Antonio Candido, que em 1968 se referia às "transições quase imperceptíveis que unificam a diversidade do escritor" (CANDIDO, 1970, p. 32), e Silviano Santiago, que no mesmo ano de 1968 propunha: "Já é tempo de se começar a compreender a obra de Machado de Assis como um todo coerentemente organizado, percebendo que à medida que seus textos se sucedem cronologicamente certas estruturas primárias e primeiras se desarticulam sob forma de estruturas diferentes, mais complexas e mais sofisticadas" (SANTIAGO, 2000, p. 27).

Além da proposição de certa unidade na obra, Jorge de Sena refletia sobre a difícil circulação, nos grandes centros de cultura, da obra de escritores geniais que produziram suas obras em línguas e culturas consideradas menores. Com isso, o texto de Jorge de Sena se mostra em perfeita sintonia com as reflexões deste número em torno das traduções e dos modos de circulação internacional da obra de Machado de Assis.

\section{Referências}

CANDIDO, Antonio. Vários escritos. São Paulo: Duas cidades, 1970.

SANTIAGO, Silviano. Uma literatura nos trópicos: ensaios sobre dependência cultural. 2. ed. Rio de Janeiro: Rocco, 2000. 